\title{
Article \\ Kinetic Modeling of Solketal Synthesis from Glycerol and
Acetone Catalyzed by an Iron(III) Complex
}

Francesco Taddeo $\left(\mathbb{D}\right.$, Roberto Esposito * ${ }^{(\mathbb{C})}$, Vincenzo Russo *(i) and Martino Di Serio

Department of Chemical Sciences, University of Naples Federico II, Complesso Universitario di Monte Sant'Angelo, 80126 Naples, Italy; francesco.taddeo@unina.it (F.T.); diserio@unina.it (M.D.S.)

* Correspondence: roberto.esposito@unina.it (R.E.); v.russo@unina.it (V.R.)

\begin{abstract}
In the last few years, the depletion of the fossil sources and their negative effect on the environment has led to find new alternatives; among these, biodiesel is considered one of the most promising for this purpose. Biodiesel can be produced from the transesterification of vegetable oils or animal fats, obtaining glycerol as a by-product. Glycerol can be used in different processes and one of the most interesting is the condensation with acetone to produce solketal. Among its applications, plasticizers, solvents, and pharmaceutical formulations are the most common. In this work, the attention was focused on the reaction between glycerol and acetone to give solketal promoted by an iron(III) complex. The reaction mechanism was hypothesized, and the kinetics was studied in a batch reactor. Finally, the thermodynamic and kinetic parameters were determined with a reliable model investigating the phenomena that occurred in the reaction network.
\end{abstract}

Keywords: solketal; kinetics; homogeneous catalysts; modeling; glycerol

Citation: Taddeo, F.; Esposito, R.; Russo, V.; Di Serio, M. Kinetic Modeling of Solketal Synthesis from Glycerol and Acetone Catalyzed by an Iron(III) Complex. Catalysts 2021, 11, 83. https://doi.org/10.3390/ catal11010083

Received: 15 December 2020 Accepted: 7 January 2021 Published: 9 January 2021

Publisher's Note: MDPI stays neutral with regard to jurisdictional clai$\mathrm{ms}$ in published maps and institutional affiliations.

Copyright: $\odot 2021$ by the authors. Licensee MDPI, Basel, Switzerland. This article is an open access article distributed under the terms and conditions of the Creative Commons Attribution (CC BY) license (https:// creativecommons.org/licenses/by/ $4.0 /)$.

\section{Introduction}

Nowadays, the economy is mainly based on petrochemical processes starting from fossil feedstock to obtain fine chemicals, polymers, and fuels [1].

The depletion of fossil resources has led to the search of new alternatives. Among them, biofuels, above all bio-ethanol and biodiesel [2], are considered as the most interesting to replace fossil fuels that are considered harmful to the environment as well as their non-renewable nature [3].

Biodiesel can be obtained through the transesterification of animal fats or vegetable oils with alcohols, usually methanol, in the presence of base catalysts [4], producing glycerol as a by-product [5]. The European Union has proposed the use of diesel mixed with biodiesel by $10 \%$ in the field of transportation, so an increasing production of biodiesel will be expected, and by 2020, glycerol production of 41.9 billion liters per year [3].

Glycerol can be used for several applications such as food, polymers, cosmetics, and pharmaceutical industries [6,7], but increasing biodiesel production has led to an excessive amount of glycerol in the market and a subsequent decrease in its commercial value $[6,8]$. The wide use of glycerol in such different fields is due to its properties; the three hydroxyl groups produce a solubility in water and alcohols, while an insolubility in hydrocarbons [2]. The high boiling point does not make it suitable for use in the mixture with gasoline [4]. An important application of glycerol is to produce value-added chemicals due to its biodegradable and nontoxic nature [9].

In addition, the conversion of wastes or by-products of industrial processes have a double advantage in terms of Sustainability. The use of waste or by-products of other bio-refineries allows for the restriction of production loops in line with the principles of a Circular Economy. At the same time, it is an example that biomass is a chemical platform capable of potentially replacing oil and petrochemicals. Many examples in this field already exist [10-15]. 
Glycerol is involved in several reactions to obtain ethers, esters, ketals, and acetals [4], but one of the most interesting processes for the conversion of glycerol is its condensation with acetone to produce solketal [1].

Solketal, known also as 4-hydroxymethyl-2,2-dimethyl-1,3-dioxolane, is used in many applications such as nontoxic solvents, plasticizers, suspending agents in pharmaceutical formulations [16], and has a high potential as fuel additives to increase ignitability and reduce particle emissions [17-19]. Furthermore, when it is added to gasoline and biodiesel formulation, it can improve their properties, satisfying the characteristics for flash point and oxidation stability [19]. The ketalization reaction to synthesize solketal is an equilibrium reaction, which has a low equilibrium constant $[2,20]$. One of the main drawbacks of this reaction is water production [21], so to shift the equilibrium to the solketal formation, an excess of acetone or the removal of water formed during the reaction is required [2,20]. However, another problem verified in this process is the poor miscibility of glycerol and acetone at $25{ }^{\circ} \mathrm{C}$ and $1 \mathrm{~atm}$ [2]. In this reaction, the selectivity toward the main product, the five membered molecule (solketal), is very high (about 98\%) while that toward the six membered ring one, which is the by-product, is lower (about 2\%) [22]. The production of glycerol ketals occurs in the presence of an acid catalyst, both heterogeneous and homogeneous [23].

Heterogeneous catalysts with the most promising performances are cation exchange resins such as Amberlyst-15, Amberlyst-36, zeolites, heteropolyacids, and sulfonic acidmodified mesostructured silicas [21,23,24].

Homogeneous catalysts show high efficiency, but are difficult to separate from the products and cannot be reused. Among them, Brønsted acids such as $p$-toluenesulfonic, sulfuric, and hydrochloric acid are used, but they cause the corrosion of reactors [16,21,22,25].

Switching to Lewis acid catalysis is a possible solution to overcome this drawback. This catalysis is widely used for the sustainable conversion of biomass and different metal salts and complexes can catalyze multiple transformations such as esterification, transesterification, oxidative cleavage of double bonds, and many others [26-32].

Ketalization of glycerol is one of these and Menezes et al. used a $\mathrm{SnCl}_{2}$ catalyst, which shows good performances being easily recovered and reused without loss of activity [33]. Some of us proposed a class of homogeneous catalysts based on iron(III) complexes obtaining excellent results with a turn over frequency (TOF) of $10^{5} \mathrm{~h}^{-1}$ by loading a very low catalyst amount (up to 10 ppm) [18,25].

Catalysts based on this non-noble, cheap, low toxic, and abundant metal can be a sustainable choice for the catalytic conversion of the biomass or derivatives [34]. At the same time, in order to scale up the process and move toward industrial applications, it is necessary to obtain the fundamental kinetic and catalytic parameters. Some examples of these basic investigations on this reaction, using different catalysts still exist $[16,22,35,36]$.

In this work, a detailed kinetic study of solketal synthesis (Scheme 1), using a very promising homogeneous catalyst that was demonstrated to be very selective toward the solketal synthesis [18], an iron(III) complex, indicated as $\mathrm{FeCl}_{3}\left(1-\mathrm{NO}_{2}\right)$ was made. The choice of this complex was guided by different factors: the high TOF showed in previous works [18,25]; the low hygroscopicity, high air-stability, and ease of handling of the material; and the presence of the pyridinimine ligand that allows for tunability of the acidity of the metal and can be the starting point for the synthesis of a supported homogeneous catalyst.

The reaction was conducted in a batch reactor investigating the effect of different operative conditions (e.g., temperature, catalyst load, and reactants' molar ratio) on the reaction rate. A mathematical model was developed to obtain the kinetic and thermodynamic parameters according to the collected experimental data. 


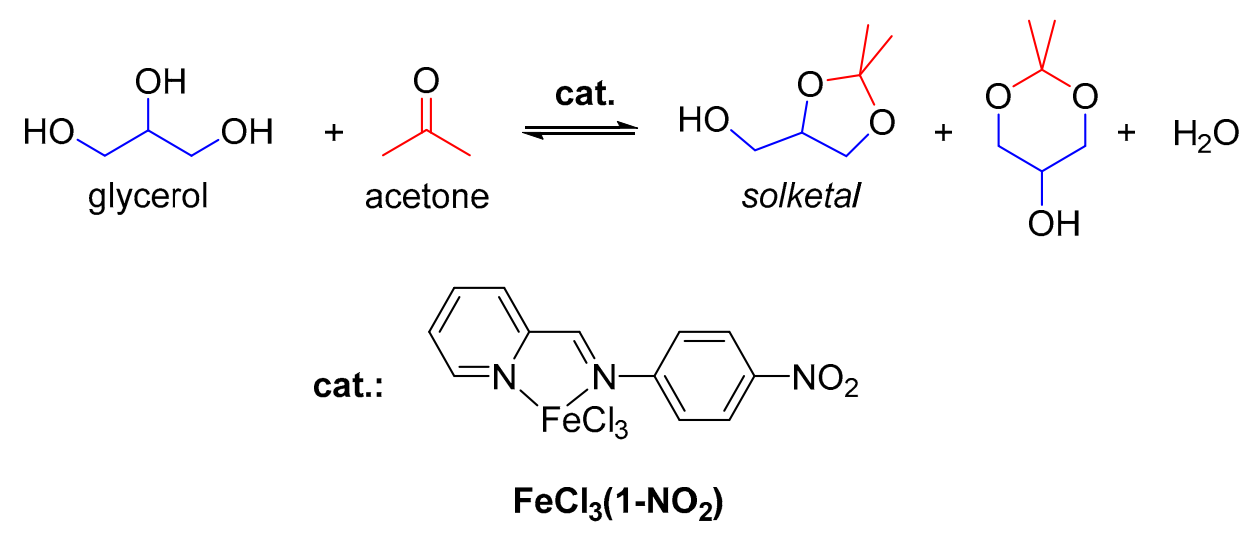

Scheme 1. Glycerol ketalization with acetone catalyzed by $\mathrm{FeCl}_{3}\left(1-\mathrm{NO}_{2}\right)$.

\section{Results and Discussion}

2.1. Kinetic Experiments of Glycerol Ketalization with Acetone Promoted by $\mathrm{FeCl}_{3}\left(1-\mathrm{NO}_{2}\right)$

Glycerol and acetone have been demonstrated to be rather immiscible when used in a $4: 1$ acetone/glycerol molar ratio $[37,38]$, and it is important to verify if eventual liquidliquid mass transfer limitations occur in the adopted experimental conditions. For this purpose, experiments were first conducted by varying the stirring rate. Similar results obtained at both 400 and $600 \mathrm{rpm}$ for glycerol conversion and solketal selectivity implied the absence of liquid-liquid mass transfer limitation. The results are reported in Figure 1.

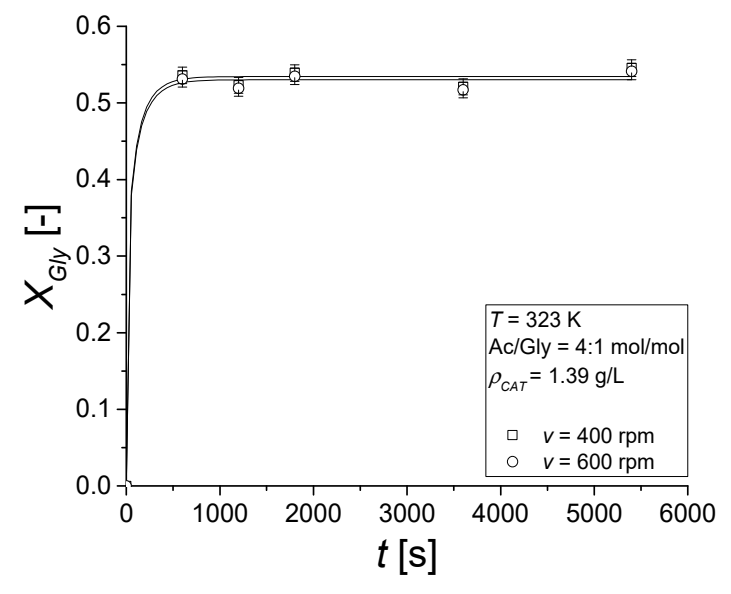

(A)

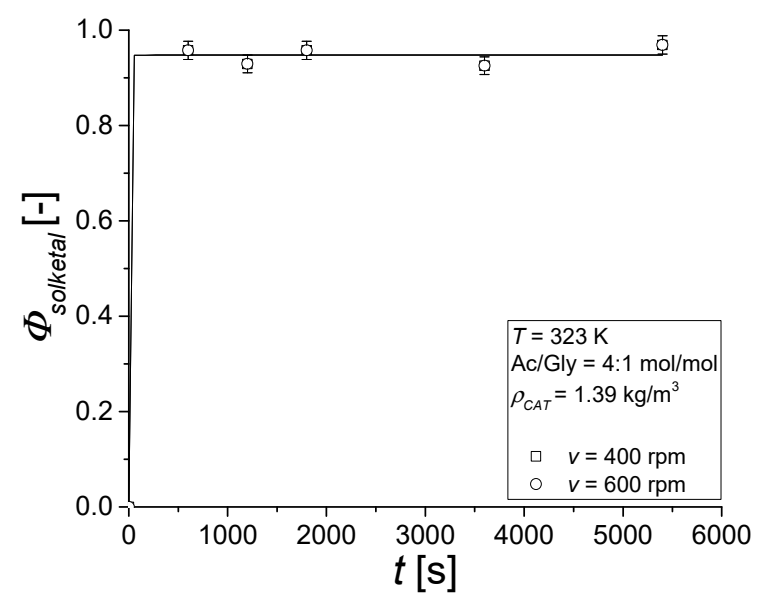

(B)

Figure 1. Stirring rate effect for catalyzed tests, fixing $T=323 \mathrm{~K}$, Ac $/ \mathrm{Gly}=4: 1 \mathrm{~mol} / \mathrm{mol}$, and $\rho_{\mathrm{CAT}}=1.39 \mathrm{~kg} / \mathrm{m}^{3}$. (A) Glycerol conversion. (B) Selectivity toward solketal.

As revealed, the selectivity of this reaction was almost always near unity, as previously reported in the literature for the 5-membered acetal [16,39]. This aspect is mainly due to the thermodynamic stability of this compound compared to the 6-membered acetal and the mechanism favoring its production with respect to by-product.

Tests were performed at different temperatures (see Table 1 for details) to evaluate its effect on the reaction rate. 
Table 1. Operation conditions for both blank (B) and catalyzed (C) kinetic experiments.

\begin{tabular}{ccccc}
\hline Run & $v[\mathbf{r p m}]$ & T $[\mathbf{K}]$ & Ac/Gly $[\mathbf{m o l} / \mathbf{m o l}]$ & $\rho_{\text {CAT }}\left[\mathbf{k g} / \mathbf{m}^{3}\right]$ \\
\hline B & 400 & 323 & $4: 1$ & - \\
\hline C1 & 600 & 323 & $4: 1$ & 1.39 \\
\hline C2 & 400 & 323 & $4: 1$ & 1.39 \\
\hline C3 & 400 & 323 & $4: 1$ & 2.62 \\
\hline C4 & 400 & 323 & $4: 1$ & 0.67 \\
\hline C5 & 400 & 323 & $4: 1$ & 0.33 \\
\hline C6 & 400 & 323 & $4: 1$ & 0.08 \\
\hline C7 & 400 & 323 & $4: 1$ & 0.04 \\
\hline C8 & 400 & 323 & $4: 1$ & 0.02 \\
\hline C9 & 400 & 313 & $4: 1$ & 0.02 \\
\hline C10 & 400 & 303 & $4: 1$ & 0.02 \\
\hline C11 & 400 & 303 & $4: 1$ & 0.04 \\
\hline C12 & 400 & 303 & $4: 1$ & 0.08 \\
\hline C13 & 400 & 303 & $4: 1$ & 0.25 \\
\hline
\end{tabular}

From the experiments conducted at different temperature values, it can be verified that by increasing the temperature, the glycerol conversion also increased, while the solketal selectivity was similar in each test. The results are shown in Figure 2.

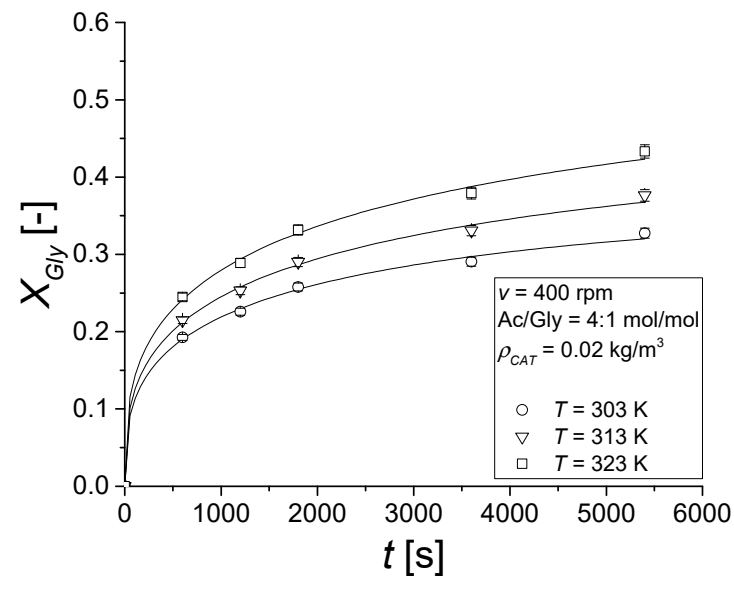

(A)

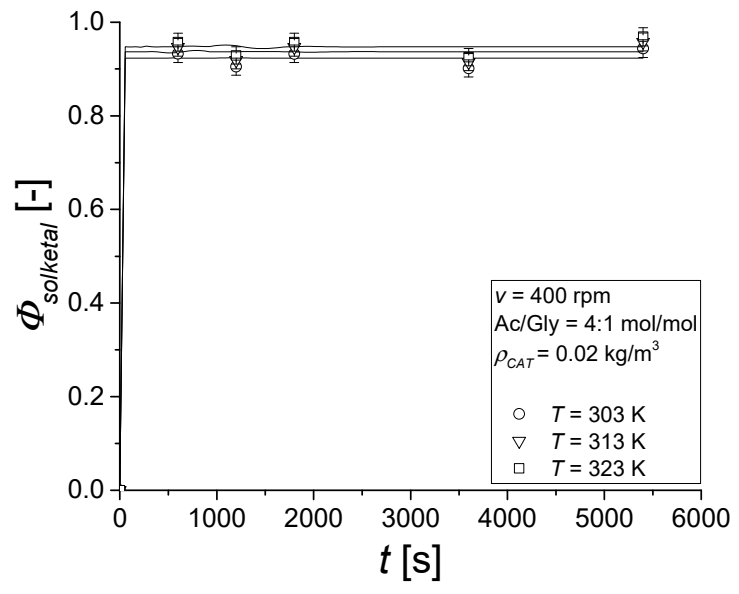

(B)

Figure 2. Temperature effect for catalyzed tests, fixing $v=400 \mathrm{rpm}, \mathrm{Ac} / \mathrm{Gly}=4: 1 \mathrm{~mol} / \mathrm{mol}$, and $\rho_{\text {CAT }}=0.02 \mathrm{~kg} / \mathrm{m}^{3}$. (A) Glycerol conversion. (B) Selectivity toward solketal.

Two sets of experiments were made by evaluating the effect of the catalyst load on the reaction rate at two different temperature values. The first set was conducted at $\mathrm{T}=323 \mathrm{~K}$, while the second at $\mathrm{T}=303 \mathrm{~K}$.

The blank test (Table 1, Run B) showed that glycerol conversion was close to 0 , so the reaction rate without a catalyst can be considered negligible.

For the experiments performed at $323 \mathrm{~K}$, similar results were obtained in terms of glycerol conversion, except for those with a lower catalyst concentration $\left(0.04 \mathrm{~kg} / \mathrm{m}^{3}\right.$ and $0.02 \mathrm{~kg} / \mathrm{m}^{3}$ ) (see Figure 3A). It was possible to note that over the catalyst concentration of $0.33 \mathrm{~kg} / \mathrm{m}^{3}$, glycerol conversion became invariant with the catalyst load. This effect probably occurred because beyond a determined value of the catalyst load, the step of the 
reaction catalyzed by $\mathrm{FeCl}_{3}\left(1-\mathrm{NO}_{2}\right)$ was no longer the limiting one, but the dehydration, which occurred independently of the catalyst, became the limiting step.

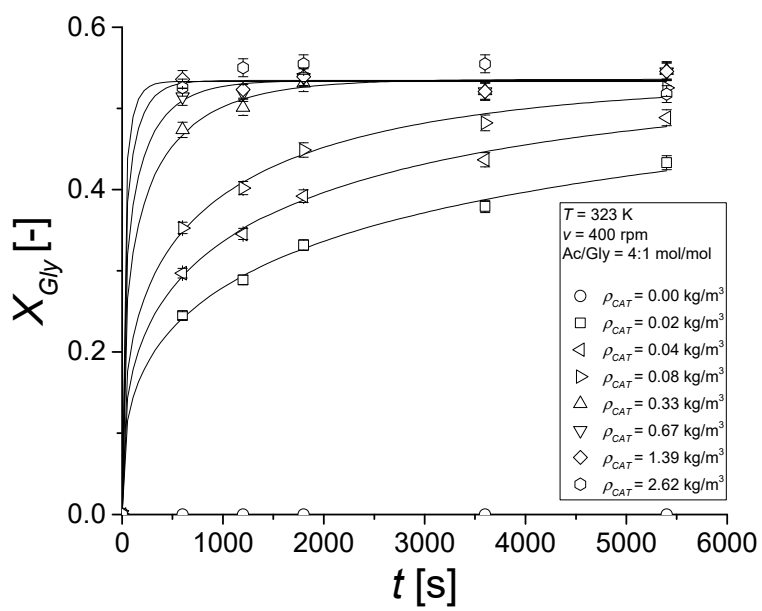

(A)

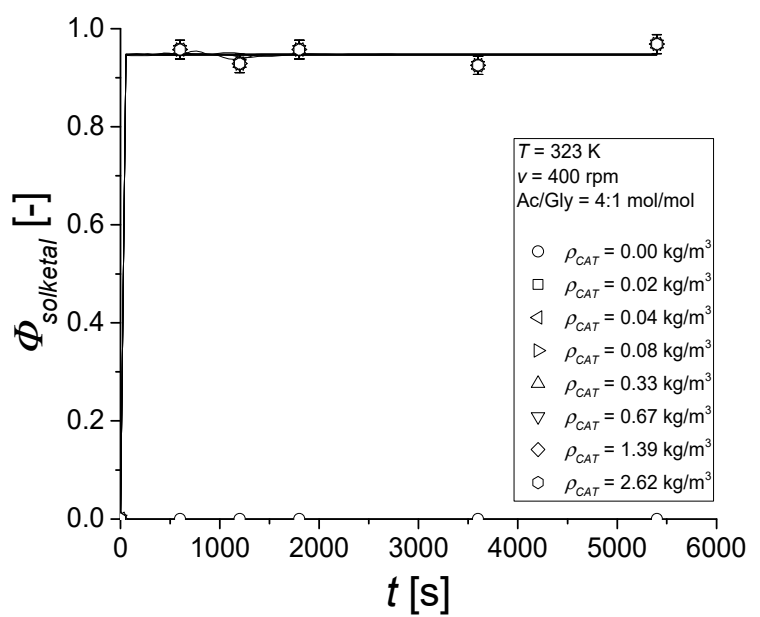

(B)

Figure 3. Catalyst load effect for catalyzed tests, fixing $v=400 \mathrm{rpm}$, Ac/Gly =4:1 $\mathrm{mol} / \mathrm{mol}$, and $T=323 \mathrm{~K}$. (A) Glycerol conversion. (B) Selectivity toward solketal.

Lower conversion was reached in the experiments conducted at $303 \mathrm{~K}$ with respect to those performed at $323 \mathrm{~K}$ (Figure $4 \mathrm{~A}$ ). In both cases, similar values of solketal selectivity were obtained; a little variation occurred as the catalyst concentration changed, as reported in Figures 3B and 4B.

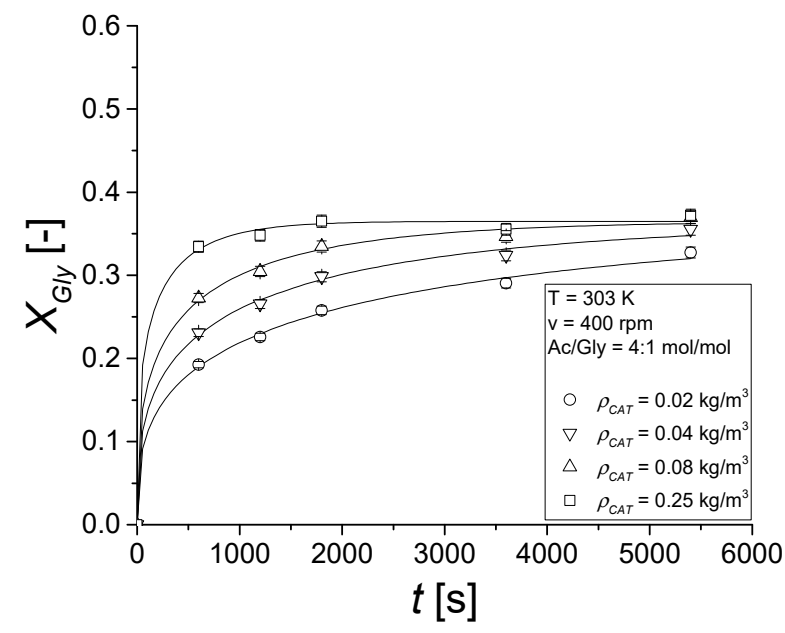

(A)

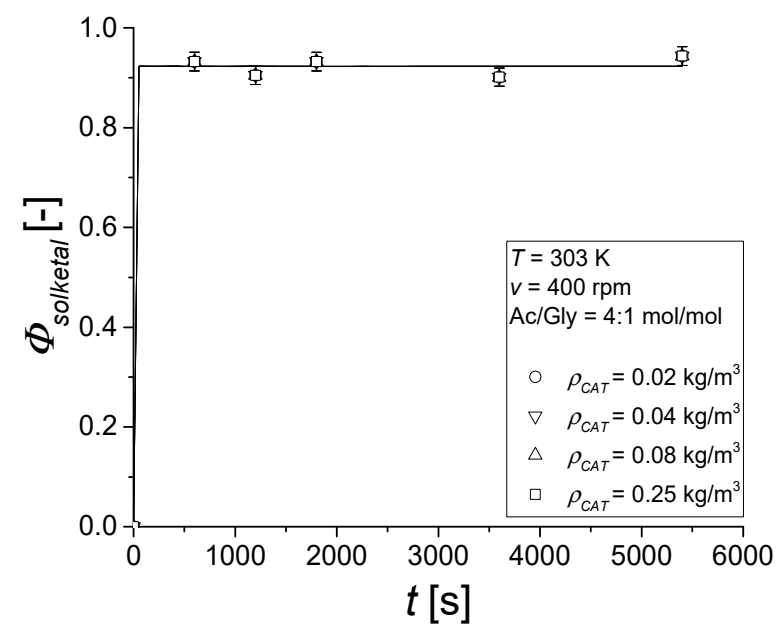

(B)

Figure 4. Catalyst load effect for catalyzed tests, fixing v $=400 \mathrm{rpm}$, Ac/Gly = 4:1 mol/mol, and T= $303 \mathrm{~K}$. (A) Glycerol conversion. (B) Selectivity toward solketal.

\subsection{Kinetic Modeling}

The hypothesized mechanism consisted of three reactions: (i) formation of the activated form of the iron-based catalyst $\left(\mathrm{Fe}^{*} \mathrm{Cl}_{3}\left(1-\mathrm{NO}_{2}\right)\right)$ by coordination of the carbonyl oxygen of acetone to the metal center; (ii) reaction between glycerol and the activated catalyst to obtain solketal through the nucleophilic attack of an oxygen of the glycerol to the carbonylic carbon of the coordinated acetone, the subsequent ring closure, and release of a molecule of water; and (iii) the analogous reaction between glycerol and the 
activated catalyst to obtain the by-product. The scheme of this mechanism is reported below (Scheme 2).

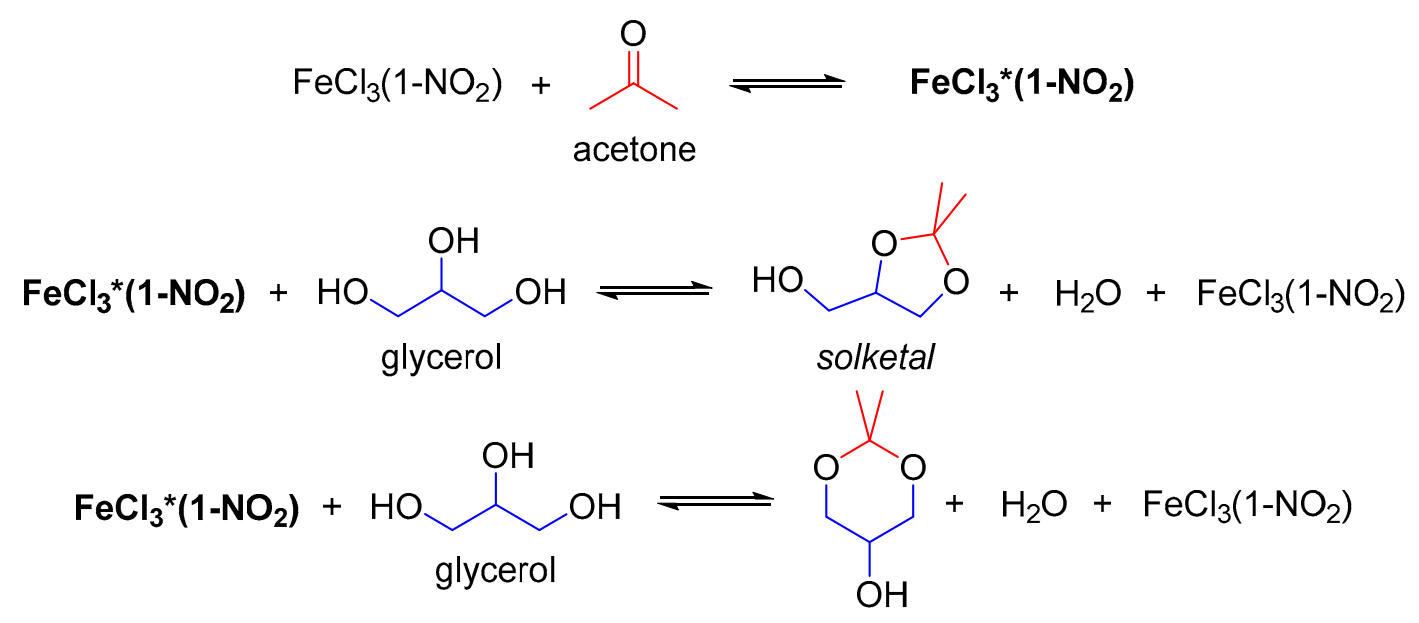

Scheme 2. Glycerol ketalization reaction scheme: (i) coordination of acetone to Fe(III) complex; (ii) glycerol ketalization to solketal; and (iii) glycerol ketalization to the by-product.

This mechanism is similar to that previously reported for a hexaaquairon(III) ion supported by a theoretical study [18] and is also in line with the mechanisms proposed in the literature for iron nitrate [40] and previously for others like Lewis acid catalysts [2].

The collected experimental data were interpreted with a reliable kinetic model considering the aforementioned mechanism. The reaction rates are expressed by Equations (1)-(3).

$$
\begin{gathered}
r_{1}=k_{1}\left(c_{\mathrm{FeCl}_{3}\left(1-\mathrm{NO}_{2}\right)} c_{\mathrm{Ac}}-\frac{1}{K_{1}} c_{\mathrm{Fe} * \mathrm{Cl}_{3}\left(1-\mathrm{NO}_{2}\right)}\right) \\
r_{2}=k_{2}\left(c_{\mathrm{Fe} * \mathrm{Cl}_{3}\left(1-\mathrm{NO}_{2}\right)} c_{\mathrm{Gly}}-\frac{1}{K_{2}} c_{\mathrm{FeCl}}\left(1-\mathrm{NO}_{2}\right) c_{\text {solketal }} c_{\mathrm{H}_{2} \mathrm{O}}\right) \\
r_{3}=k_{3}\left(c_{\mathrm{Fe} * \mathrm{Cl}_{3}\left(1-\mathrm{NO}_{2}\right)} c_{\mathrm{Gly}}-\frac{1}{K_{3}} c_{\mathrm{FeCl}_{3}\left(1-\mathrm{NO}_{2}\right)} c_{B P} c_{\mathrm{H}_{2} \mathrm{O}}\right)
\end{gathered}
$$

A modified Arrhenius and the van't Hoff equations (Equations (4) and (5)) were used in the model to express the relation between the kinetic and equilibrium constants and temperature for the three reactions reported in Scheme 2.

$$
\begin{gathered}
k=k_{r e f} \exp \left(-\frac{E a}{R}\left(\frac{1}{T}-\frac{1}{T_{r e f}}\right)\right) \\
K=K_{r e f} \exp \left(-\frac{\Delta_{r} H}{R}\left(\frac{1}{T}-\frac{1}{T_{r e f}}\right)\right)
\end{gathered}
$$

The reference temperature was fixed at $T_{\text {ref }}=303 \mathrm{~K}$.

The mass balance equation, reported in Equation (6), was used in the model to describe the variation of each component with the reaction time.

$$
\frac{d c_{i}}{d t}=v_{i} r
$$

In Figures 1-4, it is possible to see the good agreement between the experimental and fitted data.

As reported in Figure 5A,B, the non-activated form of the catalyst disappeared for short times from the beginning of the reaction while at the same time, the amount of the catalyst in the activated form increased. 


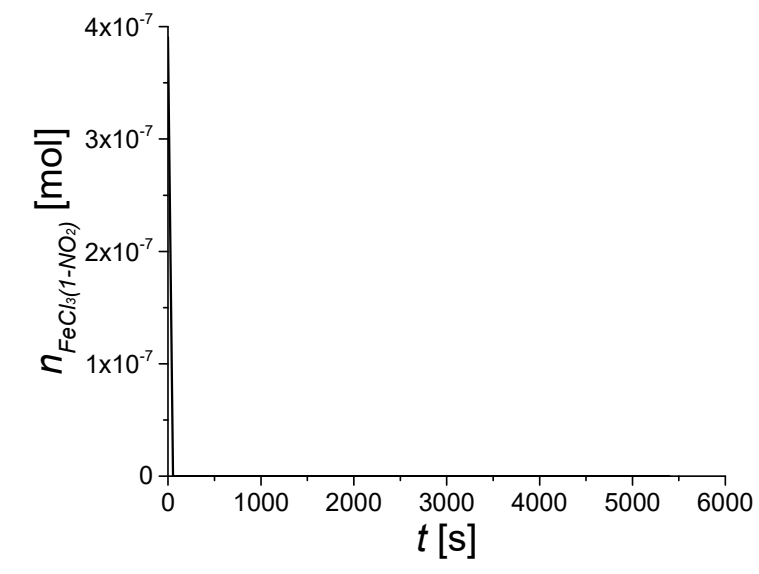

A.

Figure 5. Catalyst forms vs. time. (A) Non-activated form. (B) Activated form.

Thanks to these results, it was possible to use a simplified model to estimate the kinetic and thermodynamic parameters neglecting the non-activated catalyst form. Furthermore, in this model, the reaction that led to the formation of the by-product (Equation (3)) was neglected since the selectivity toward solketal was close to the unity, as possible to see from Figures 1-4 and as already reported [18].

In Table 2, the kinetic and thermodynamic parameters obtained from the parameter estimation are listed.

Table 2. Parameter estimation results. CI: confidence interval at 95\%.

\begin{tabular}{|c|c|c|c|}
\hline & Value & $95 \% \mathrm{CI}$ & Units \\
\hline$\Delta_{\mathrm{r}} H_{1}$ & 30 & 1 & $\mathrm{~kJ} / \mathrm{mol}$ \\
\hline$\Delta_{\mathrm{r}} H_{2}$ & 16.4 & 0.5 & $\mathrm{~kJ} / \mathrm{mol}$ \\
\hline$E a_{1}$ & 13.0 & 0.5 & $\mathrm{~kJ} / \mathrm{mol}$ \\
\hline$E a_{2}$ & 64 & 2 & $\mathrm{~kJ} / \mathrm{mol}$ \\
\hline$E a_{3}$ & 63 & 3 & $\mathrm{~kJ} / \mathrm{mol}$ \\
\hline$K_{r e f, 1}$ & 0.55 & 0.05 & - \\
\hline$K_{r e f, 2}$ & 0.10 & 0.02 & - \\
\hline$K_{r e f, 3}$ & $8.1 \times 10^{-3}$ & $0.1 \times 10^{-3}$ & - \\
\hline$k_{r e f, 1}$ & 620 & 10 & $\left(\mathrm{~m}^{3} / \mathrm{mol}\right) \mathrm{s}^{-1}$ \\
\hline$k_{r e f, 2}$ & $14.0 \times 10^{7}$ & $0.2 \times 10^{7}$ & $\left(\mathrm{~m}^{3} / \mathrm{mol}\right) \mathrm{s}^{-1}$ \\
\hline$k_{r e f, 3}$ & $42.0 \times 10^{5}$ & $0.5 \times 10^{5}$ & $\left(\mathrm{~m}^{3} / \mathrm{mol}\right) \mathrm{s}^{-1}$ \\
\hline
\end{tabular}

From the parity plots reported in Figure $6 \mathrm{~A}, \mathrm{~B}$, it is possible to demonstrate that for both the glycerol conversion and solketal selectivity, all the data collected in the experiments fell in an error window of $5 \%$. 


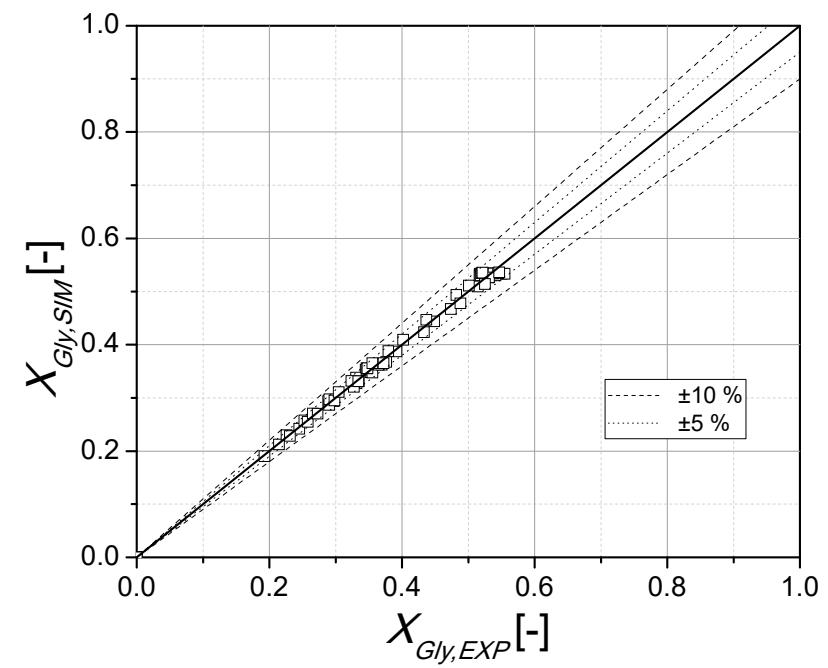

(A)

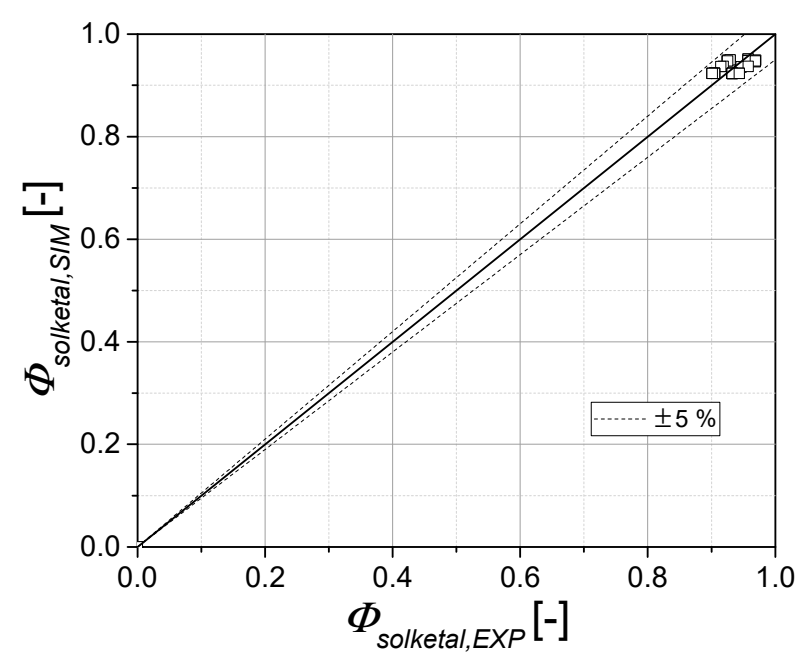

(B)

Figure 6. Parity plot for all the experimental data. (A) Glycerol conversion. (B) Solketal selectivity.

\section{Materials and Method}

\subsection{Materials}

All the reagents used in the kinetic experiments and for the catalyst preparation were purchased at the highest purity level by Merck KGAA, Darmstadt, Germany.

\subsection{Catalyst Preparation}

$\mathrm{FeCl}_{3}\left(1-\mathrm{NO}_{2}\right)$ : To a solution of 2-pyridinecarboxaldehyde $(535 \mathrm{mg}, 5.0 \mathrm{mmol})$ and 4-nitroaniline (771 mg, $5.0 \mathrm{mmol}$ ) in diethyl ether, anhydrous iron(III) chloride ( $810 \mathrm{mg}$, $5.0 \mathrm{mmol}$ ) was added. A yellow precipitate appeared, and the mixture was left at room temperature, under magnetic stirring for $30 \mathrm{~min}$. After that time, the yellow solid was recovered by filtration, washed three times with diethyl ether, and finally dried in vacuum ( $90 \%$ yield). The compound was characterized by UV-Vis and IR, and the results compared with those reported in the literature [25]. UV-Vis in acetone: $363 \mathrm{~nm}\left(\lambda_{\max }\right)$. Imine IR stretching (in nujol): $1626 \mathrm{~cm}^{-1}$.

\subsection{Reactor Setup and Procedure}

The ketalization reaction was performed in a $0.3 \mathrm{~L}$ Hastelloy autoclave, equipped with a magnetically driven stirrer that allowed for the mixing of the reaction mixture with variable stirring through a control system. The reaction temperature was set and controlled through a thermoregulator connected to a heating jacket. In addition, a tank in which the catalyst was placed, was connected to the vessel. About $180 \mathrm{~g}$ of solution was weighed in the reactor, while the catalyst, dissolved in about $20 \mathrm{~g}$ of acetone, was loaded in the tank. The reactor was pre-heated at the desired temperature level and was pressurized with nitrogen to 5 bar to avoid the partition of the lowest boiling component between the gas and liquid phases. The catalyst solution was loaded into the vessel thanks to the nitrogen flow, after that, the desired temperature was reached. This time was considered as the starting point of the reaction and from this moment, samples were withdrawn at regular intervals to follow the reaction kinetics.

A first test (B in Table 1) was conducted in the absence of the catalyst, while the catalyzed experiments (listed with $C$ in Table 1 ) were performed by varying stirring rate, temperature, and catalyst load.

Samples were analyzed through ${ }^{1} \mathrm{H}-\mathrm{NMR}$ to evaluate the glycerol conversion and the selectivity toward solketal. 


\subsection{Analytical Method}

Samples were analyzed by ${ }^{1} \mathrm{H}-\mathrm{NMR}$ with a Bruker Avance Ultrashield (Bruker Corporation, Billerica, MA, USA) operating at a proton frequency of $400 \mathrm{MHz}$ using $\mathrm{D}_{2} \mathrm{O}$ as the solvent. The conversion was obtained by integrating the signals of methyl groups resonating at a chemical shift between 1.55 and $1.35 \mathrm{ppm}$ (in red in Figure 7) and by comparing this integral $\left(I_{r}\right)$ with the integral $\left(I_{b}\right)$ of the signal resonating between 4.55 and $3.50 \mathrm{ppm}$ (in blue in Figure 7), which corresponded to the signal of the proton of the glyceryl group of both the reactant (glycerol) and products (solketal and 2,2-dimethyl-1,3-dioxan-5-ol). The conversion $\left(X_{G l y}\right)$ was calculated as follows:

$$
X_{G l y}=\frac{5 I_{r}}{6 I_{b}}
$$

The selectivity toward solketal was calculated comparing the integral $\left(I_{2}\right)$ of signals resonating at $1.51 \mathrm{ppm}$ (named 2 in Figure 7, corresponding to protons of a methyl of 2,2-dimethyl-1,3-dioxan-5-ol) and $1.41 \mathrm{ppm}$ (named 1 in Figure 7, corresponding to protons of a methyl solketal). The selectivity ( $\left.\phi_{\text {solketal }}\right)$ was calculated as follows:

$$
\phi_{\text {solketal }}=1-\frac{I_{2}}{I_{1}}
$$
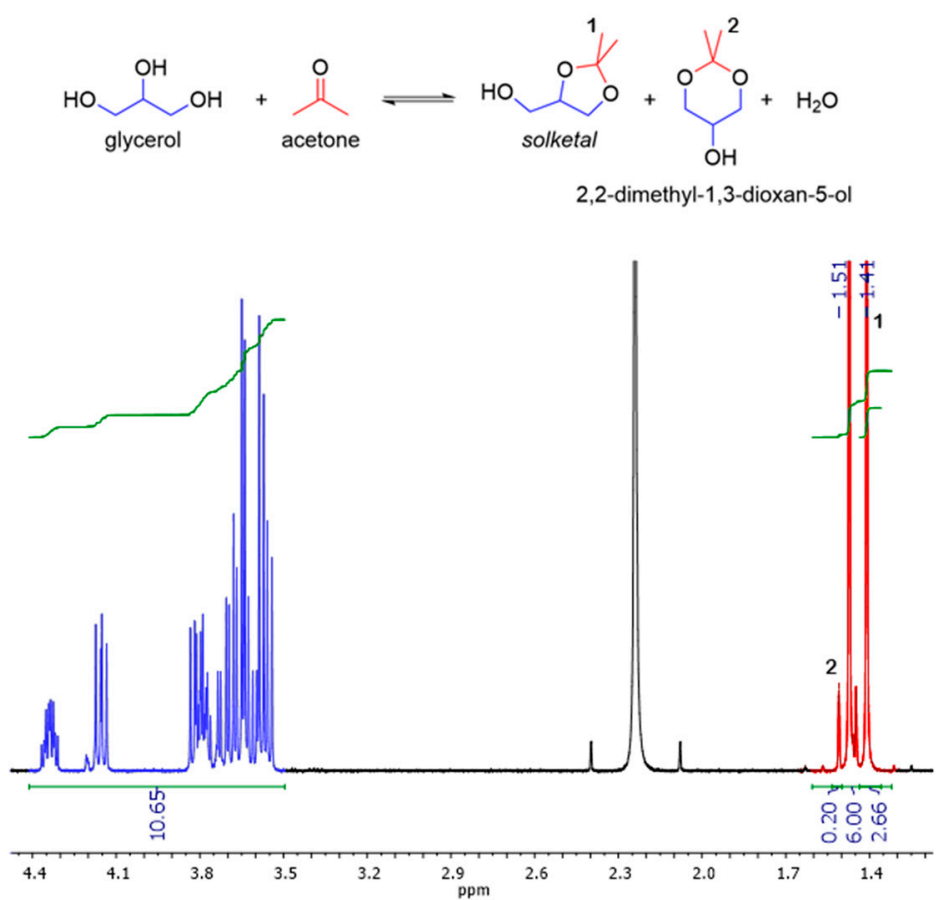

Figure 7. ${ }^{1} \mathrm{H}-\mathrm{NMR}$ spectrum of a typical reaction mixture. In red, the integrals corresponding to the protons of the methyls of products, and in blue, the signals of the glyceryl portion of both the reactant and products.

\section{Conclusions}

The kinetics of the solketal synthesis promoted by an iron(III) complex was investigated. A reaction mechanism that consisted of three main steps was hypothesized as follows: (i) formation of the activated form of the iron-based catalyst $\left(\mathrm{FeCl}_{3}{ }^{*}\left(1-\mathrm{NO}_{2}\right)\right)$; (ii) reaction between glycerol and the activated catalyst to obtain solketal; and (iii) reaction between glycerol and the activated catalyst to obtain the by-product. The reaction to obtain the by-product was neglected in the model since the selectivity toward solketal was close to the unity. 
The activated form of the catalyst increased rapidly at the beginning of the reaction, while the non-activated form existed only in the first period from the beginning of the reaction itself.

The collected experimental data were elaborated with a reliable reactor model estimating the kinetic and thermodynamic parameters. The obtained results showed a good agreement between the experimental and the simulated curves.

Author Contributions: F.T.: Data curation, Formal analysis, Writing—original draft. R.E.: Conceptualization, Investigation, Supervision, Writing - review \& editing. V.R.: Conceptualization, Investigation, Supervision, Writing — review \& editing. M.D.S.: Project administration, Supervision, Writing - review \& editing. All authors have read and agreed to the published version of the manuscript.

Funding: This research received no external funding.

Institutional Review Board Statement: Not applicable.

Informed Consent Statement: Not applicable.

Data Availability Statement: All the data of this study are presented within this paper itself and are openly available.

Acknowledgments: The authors wish to thank the European Union (FSE, PON Ricerca e Innovazione 2014-2020, Azione I.1 “Dottorati Innovativi con caratterizzazione Industriale”) for funding a PhD grant to Francesco Taddeo. Roberto Esposito thanks the European Union and MIUR for funding through PON-AIM project code E61G19000090002, proposal code AIM1829571-1. Simone Silvestro is acknowledged for their experimental support.

Conflicts of Interest: The authors declare no conflict of interest.

\section{Abbreviations}

$\begin{array}{ll}\text { Ac } & \text { Acetone } \\ \text { BP } & \text { By-product } \\ \text { CI } & \text { Confidence interval } \\ \text { EXP } & \text { Experimental data } \\ \text { Gly } & \text { Glycerol } \\ \text { SIM } & \text { Simulated data } \\ \text { List of Symbols } & \text { Explanation } \\ c_{i} & \text { Concentration of component } i\left[\mathrm{~mol} / \mathrm{m}^{3}\right] \\ E a & \text { Activation energy of reaction }\left[\mathrm{kJ} / \mathrm{mol}^{-}\right] \\ K & \text { Equilibrium constant }[-] \\ K_{\text {ref }} & \text { Reference equilibrium constant }[-] \\ k & \text { Kinetic constant }\left[\left(\mathrm{m}^{3} / \mathrm{mol}^{-1} \mathrm{~s}^{-1}\right]\right. \\ k_{\text {ref }} & \text { Reference kinetic constant }\left[\left(\mathrm{m}^{3} / \mathrm{mol}\right) \mathrm{s}^{-1}\right] \\ r & \text { Rate of the reaction }\left[\mathrm{mol} /\left(\mathrm{m}^{3} \mathrm{~s}\right)\right] \\ R & \text { Ideal gas constant }[\mathrm{kJ} /(\mathrm{K} \mathrm{mol})] \\ t & \text { Time [s] } \\ T & \text { Temperature }[\mathrm{K}] \\ T_{\text {ref }} & \text { Reference temperature }(303 \mathrm{~K})[\mathrm{K}] \\ v & \text { Stirring speed }[\mathrm{rpm}] \\ X_{G l y} & \text { Glycerol conversion degree }[-] \\ \text { Greek Letters } & \\ \Delta_{\mathrm{r}} H & \text { Reaction enthalpy }[\mathrm{kJ} / \mathrm{mol}] \\ \eta & \text { Catalyst form }[\mathrm{mol}] \\ v_{i} & \text { Stoichiometric coefficient of component } i[-] \\ \rho_{C A T} & \text { Catalyst bulk density }\left[\mathrm{kg} / \mathrm{m}^{3}\right] \\ \left.\phi_{\text {solketal }}\right] & \text { Selectivity towards solketal }[-]\end{array}$




\section{References}

1. Li, L.; Korányi, T.I.; Sels, B.F.; Pescarmona, P.P. Highly-efficient conversion of glycerol to solketal over heterogeneous Lewis acid catalysts. Green Chem. 2012, 14, 1611-1619. [CrossRef]

2. Nanda, M.R.; Zhang, Y.; Yuan, Z.; Qin, W.; Ghaziaskar, H.S.; Xu, C.C. Catalytic conversion of glycerol for sustainable production of solketal as a fuel additive: A review. Renew. Sustain. Energy Rev. 2016, 56, 1022-1031. [CrossRef]

3. Ilgen, O.; Yerlikaya, S.; Akyurek, F.O. Synthesis of Solketal from Glycerol and Acetone over Amberlyst-46 to Produce an Oxygenated Fuel Additive. Period. Polytech. Chem. Eng. 2016, 61, 144-148. [CrossRef]

4. Mota, C.J.A.; da Silva, C.X.A.; Rosenbach, N.; Costa, J.; Da Silva, F. Glycerin Derivatives as Fuel Additives: The Addition of Glycerol/Acetone Ketal (Solketal) in Gasolines. Energy Fuels 2010, 24, 2733-2736. [CrossRef]

5. Suriyaprapadilok, N.; Kitiyanan, B. Synthesis of Solketal from Glycerol and Its Reaction with Benzyl Alcohol. Energy Procedia 2011, 9, 63-69. [CrossRef]

6. Gui, Z.; Zahrtmann, N.; Saravanamurugan, S.; Reyero, I.; Qi, Z.; Bañares, M.A.; Riisager, A.; García-Suárez, E.J. Brønsted Acid Ionic Liquids (BAILs) as Efficient and Recyclable Catalysts in the Conversion of Glycerol to Solketal at Room Temperature. Chem. 2016, 1, 5869-5873. [CrossRef]

7. da Silva, G.P.; De Lima, C.J.B.; Contiero, J. Production and productivity of 1,3-propanediol from glycerol by Klebsiella pneuoniae GLC29. Catal. Today 2015, 257, 259-266. [CrossRef]

8. Royon, D.; Locatelli, S.; Gonzo, E. Ketalization of glycerol to solketal in supercritical acetone. J. Supercrit. Fluids 2011, 58, 88-92. [CrossRef]

9. Zhou, C.-H.; Beltramini, J.N.; Fan, Y.-X.; Lu, G.Q. (Max) Chemoselective catalytic conversion of glycerol as a biorenewable source to valuable commodity chemicals. Chem. Soc. Rev. 2008, 37, 527-549. [CrossRef]

10. Tuck, C.O.; Pérez, E.; Horváth, I.T.; Sheldon, R.A.; Poliakoff, M. Valorization of Biomass: Deriving More Value from Waste. Science 2012, 337, 695-699. [CrossRef]

11. Sheldon, R.A. Green chemistry and resource efficiency: Towards a green economy. Green Chem. 2016, 18, 3180-3183. [CrossRef]

12. Biermann, U.; Bornscheuer, U.; Meier, M.A.; Metzger, J.O.; Schäfer, H.J. Oils and Fats as Renewable Raw Materials in Chemistry. Angew. Chem. Int. Ed. 2011, 50, 3854-3871. [CrossRef] [PubMed]

13. Turco, R.; Tesser, R.; Cucciolito, M.E.; Fagnano, M.; Ottaiano, L.; Mallardo, S.; Malinconico, M.; Santagata, G.; Di Serio, M. Cynara cardunculus Biomass Recovery: An Eco-Sustainable, Nonedible Resource of Vegetable Oil for the Production of Poly(lactic acid) Bioplasticizers. ACS Sustain. Chem. Eng. 2019, 7, 4069-4077. [CrossRef]

14. Benessere, V.; Cucciolito, M.E.; De Santis, A.; Di Serio, M.; Esposito, R.; Melchiorre, M.; Nugnes, F.; Paduano, L.; Ruffo, F. A Sustainable Process for the Production of Varnishes Based on Pelargonic Acid Esters. J. Am. Oil Chem. Soc. 2019, 96, 443-461. [CrossRef]

15. Russo, V.; Taddeo, F.; Cogliano, T.; Vitiello, R.; Esposito, R.; Tesser, R.; Salmi, T.; Di Serio, M. Investigation of the intrinsic reaction kinetics and the mass transfer phenomena of nonanoic acid esterification with 2-ethylhexanol promoted by Sulfuric acid or Amberlite IR120. Chem. Eng. J. 2020, 127236. [CrossRef]

16. Esteban, J.; Ladero, M.; García-Ochoa, F. Kinetic modelling of the solventless synthesis of solketal with a sulphonic ion exchange resin. Chem. Eng. J. 2015, 269, 194-202. [CrossRef]

17. Alsawalha, M. Catalytic Activity and Kinetic Modeling of Various Modules HZMS-5 and Treated MCM-41 Catalysts, for the Liquid-Phase Ketalization of Glycerol With Acetone. Front. Chem. 2019, 7, 799. [CrossRef]

18. Esposito, R.; Raucci, U.; Cucciolito, M.E.; Di Guida, R.; Scamardella, C.; Rega, N.; Ruffo, F. Iron(III) Complexes for Highly Efficient and Sustainable Ketalization of Glycerol: A Combined Experimental and Theoretical Study. ACS Omega 2019, 4, 688-698. [CrossRef]

19. Reddy, P.S.; Sudarsanam, P.; Mallesham, B.; Raju, G.; Reddy, B.M. Acetalisation of glycerol with acetone over zirconia and promoted zirconia catalysts under mild reaction conditions. J. Ind. Eng. Chem. 2011, 17, 377-381. [CrossRef]

20. Clarkson, J.S.; Walker, A.J.; Wood, M.A. Continuous Reactor Technology for Ketal Formation: An Improved Synthesis of Solketal. Org. Process. Res. Dev. 2001, 5, 630-635. [CrossRef]

21. Vicente, G.; Melero, J.A.; Morales, G.; Paniagua, M.; Martín, E. Acetalisation of bio-glycerol with acetone to produce solketal over sulfonic mesostructured silicas. Green Chem. 2010, 12, 899-907. [CrossRef]

22. Rossa, V.; Pessanha, Y.D.S.P.; Díaz, G.C.; Câmara, L.D.T.; Pergher, S.B.C.; Aranda, D.A.G. Reaction Kinetic Study of Solketal Production from Glycerol Ketalization with Acetone. Ind. Eng. Chem. Res. 2017, 56, 479-488. [CrossRef]

23. Maksimov, A.L.; Nekhaev, A.I.; Ramazanov, D.N.; Arinicheva, Y.; Dzyubenko, A.A.; Khadzhiev, S.N.; Maximov, A.L. Preparation of high-octane oxygenate fuel components from plant-derived polyols. Pet. Chem. 2011, 51, 61-69. [CrossRef]

24. Ferreira, P.; Fonseca, I.; Ramos, A.; Vital, J.; Castanheiro, J. Valorisation of glycerol by condensation with acetone over silicaincluded heteropolyacids. Appl. Catal. B: Environ. 2010, 98, 94-99. [CrossRef]

25. Esposito, R.; Cucciolito, M.E.; D’Amora, A.; Di Guida, R.; Montagnaro, F.; Ruffo, F. Highly efficient iron(III) molecular catalysts for solketal production. Fuel Process. Technol. 2017, 167, 670-673. [CrossRef]

26. Melchiorre, M.; Amendola, R.; Benessere, V.; Cucciolito, M.E.; Ruffo, F.; Esposito, R. Solvent-free transesterification of methyl levulinate and esterification of levulinic acid catalyzed by a homogeneous iron(III) dimer complex. Mol. Catal. 2020, $483,110777$. [CrossRef] 
27. Esposito, R.; Melchiorre, M.; Annunziata, A.; Cucciolito, M.E.; Ruffo, F. Emerging catalysis in biomass valorisation: Simple Zn(II) catalysts for fatty acids esterification and transesterification. ChemCatChem 2020, 12, 5858. [CrossRef]

28. Benessere, V.; Cucciolito, M.E.; Dal Poggetto, G.; Di Serio, M.; Granados, M.L.; Ruffo, F.; Vitagliano, A.; Vitiello, R. Strategies for immobilizing homogeneous zinc catalysts in biodiesel production. Catal. Commun. 2014, 56, 81-85. [CrossRef]

29. Benessere, V.; Cucciolito, M.E.; Esposito, R.; Lega, M.; Turco, R.; Ruffo, F.; Di Serio, M. A novel and robust homogeneous supported catalyst for biodiesel production. Fuel 2016, 171, 1-4. [CrossRef]

30. Benessere, V.; Cucciolito, M.E.; De Santis, A.; Di Serio, M.; Esposito, R.; Ruffo, F.; Turco, R. Sustainable Process for Production of Azelaic Acid Through Oxidative Cleavage of Oleic Acid. J. Am. Oil Chem. Soc. 2015, 92, 1701-1707. [CrossRef]

31. Melchiorre, M.; Benessere, V.; Cucciolito, M.E.; Melchiorre, C.; Ruffo, F.; Esposito, R. Direct and Solvent-Free Oxidative Cleavage of Double Bonds in High-Oleic Vegetable Oils. ChemistrySelect 2020, 5, 1396-1400. [CrossRef]

32. Annunziata, A.; Esposito, R.; Gatto, G.; Cucciolito, M.E.; Tuzi, A.; Macchioni, A.; Ruffo, F. Iron(III) Complexes with Cross-Bridged Cyclams: Synthesis and Use in Alcohol and Water Oxidation Catalysis. Eur. J. Inorg. Chem. 2018, 2018, 3304-3311. [CrossRef]

33. Menezes, F.D.L.; Guimaraes, M.D.O.; da Silva, M.J. Highly Selective SnCl2-Catalyzed Solketal Synthesis at Room Temperature. Ind. Eng. Chem. Res. 2013, 52, 16709-16713. [CrossRef]

34. Du, H.; Deng, F.; Kommalapati, R.R.; Amarasekara, A.S. Iron based catalysts in biomass processing. Renew. Sustain. Energy Rev. 2020, 134, 110292. [CrossRef]

35. Moreira, M.; Faria, R.P.; Ribeiro, A.M.; Rodrigues, A.E. Solketal Production from Glycerol Ketalization with Acetone: Catalyst Selection and Thermodynamic and Kinetic Reaction Study. Ind. Eng. Chem. Res. 2019, 58, 17746-17759. [CrossRef]

36. Nanda, M.R.; Yuan, Z.; Qin, W.; Ghaziaskar, H.S.; Poirier, M.-A.; Xu, C.C. Thermodynamic and kinetic studies of a catalytic process to convert glycerol into solketal as an oxygenated fuel additive. Fuel 2014, 117, 470-477. [CrossRef]

37. Esteban, J.; García-Ochoa, F.; Ladero, M. Solventless synthesis of solketal with commercially available sulfonic acid based ion exchange resins and their catalytic performance. Green Process. Synth. 2017, 6, 79-89. [CrossRef]

38. Esteban, J.; Vorholt, A.J.; Behr, A.; Ladero, M.; Garcia-Ochoa, F. Liquid-Liquid Equilibria for the System Acetone + Solketal + Glycerol at (303.2, 313.2, and 323.2) K. J. Chem. Eng. Data 2014, 59, 2850-2855. [CrossRef]

39. Deutsch, J.; Martin, A.; Lieske, H. Investigations on heterogeneously catalysed condensations of glycerol to cyclic acetals. J. Catal. 2007, 245, 428-435. [CrossRef]

40. da Silva, M.J.; Rodrigues, A.A.; Pinheiro, P.F. Solketal synthesis from glycerol and acetone in the presence of metal salts: A Lewis or Brønsted acid catalyzed reaction? Fuel 2020, 276, 118164. [CrossRef] 